Bangladesh J. Zool. 42(2): 283-294, 2014

\title{
PROXIMATE COMPOSITION AND MICROBIAL QUALITY OF THREE IMPORTED AQUARIUM FISH FEEDS IN BANGLADESH
}

\author{
Md. Alamgir Kabir, Mohammad Shamsur Rahman, Anwar Hossain \\ and Shankar Chandra Mandal* \\ Department of Fisheries, Faculty of Biological Sciences, University of Dhaka, \\ Dhaka-1000, Bangladesh
}

\begin{abstract}
Proximate composition and microbial quality of three aquarium fish feeds commonly found in Bangladesh were collected from fish feed market of Dhaka city. Significantly higher moisture content $(2.12 \pm 0.06 \%)$ was found in Super NovaTM fish feed while similar moisture content was detected in other two feeds $(\mathrm{p}<0.05)$. On the other hand ash content detected in Optimum ${ }^{\mathrm{TM}}$ and Osaka $2000^{\mathrm{TM}}$ aquarium fish feed was significantly higher than that of Super Nova ${ }^{\mathrm{TM}}$ $(10.67 \pm 0.19 \%) \quad(p<0.05)$. Protein content found in Optimum тм $(42.21 \pm 0.12 \%)$ was significantly higher than that of Osaka $2000^{\mathrm{TM}}$ and Super Nova ${ }^{\mathrm{TM}}(\mathrm{p}<0.05)$. However, similar lipid content was found in Optimum ${ }^{\mathrm{TM}}(1.06 \pm 0.03 \%)$ and Super Nova ${ }^{\mathrm{TM}}(1.13 \pm 0.01 \%)$ aquarium fish feed which were significantly higher than that of Osaka 2000 aureus were found in all feeds. However Vibrio $s p$ was not found in any feed. Total bacterial count was significantly higher in Osaka $2000^{\mathrm{TM}}$ feed than that of others $(\mathrm{P}<0.05)$. However $S$. aureus was significantly higher in Super Nova ${ }^{\mathrm{TM}}$ than that of others while $E$. coli count was significantly higher in Optimum ${ }^{\mathrm{TM}}$ fish feed than that of others $(\mathrm{p}<0.05)$. Nutritional quality of the aquarium fish feed was qualified to some extent to meet the minimum requirement of the aquarium fish while microbial quality indicates some degrees of deterioration which may cause diseases of the aquarium fishes. Thus proper storage condition, hygienic handling and processing should be maintained to prevent the microbial contamination in aquarium fish feeds. There should be a monitoring cell from the government to assess the quality of this expensive imported feeds for aquarist.
\end{abstract}

Key words: Biochemical composition, Microbial quality, aquarium fish feed

\section{INTRODUCTION}

Aquarium fishes or ornamental fish rearing has became very popular in Bangladesh because of creating attractive look in houses as well in offices by their presence. Most of ornamental fishes found in Bangladesh are exotic species (Chowdhury et al. 2005). Among different ornamental fishes, gold fish and comets are now artificially managed in 'Rokomari' hatchery in the district of Feni in Chittagong division (Kangkon 2013). Aquarium fish trade is an expanding market with considerable growth in last two decades because of its operating systems and comparatively easy maintenance. Moreover it increases the sales of aquarium and its accessories like air pump, medicine and most important the

*Author for correspondence: <shankar@du.ac.bd>. 
aquarium fish feed (Cheong 1996). According to Dawes (2001) global import of ornamental fish is approximately raised to US\$ 321 million a decade ago. In which US\$ 21-48 million is involved in marine ornamental fish trade (Wood 2001). In 2000 the global whole sale value of ornamental fish was approximately US\$3 billion (Whittington and Chong 2007). Approximately 75\% freshwater aquarium fishes imported into the United States come from Southeast Asia (Chapman et al. 1997). Bangladesh has huge resources in fish diversity but in ornamental fishes it holds marginal position. Most of the ornamental fishes are trading from Katabon which located in the capital of Bangladesh the Dhaka city (Chowdhury et al. 2005).

Fish seed, feed and diseases are three major factors important for rearing of aquarium fishes where most of the cost is involved in feeding. So optimum feeding as well as best quality feed is essential in fish rearing. Good quality feed prevents the fish from diseases. Poor quality feed not only raise the rearing cost but also it favors diseases by deteriorating water quality. So feed having well nutritional and good microbial quality will reduce the cost of aquarium fish rearing as moisture level exceeding $25 \%$ in feed can deteriorate it by microbial damage (Silva and Anderson 1995). Aquarium fish feed is either plant or animal origin intended for consumption by pet fish kept in aquariums or in tanks. Fish feeds usually contain macro nutrients, trace elements and vitamins necessary to keep captive fish in good health (Guillaume et al. 2001). Approximately $80 \%$ of aquarist feed their fish exclusively prepared foods produced in flake, pellet or tablet form (Riehl and Baensch 1996). Prepared foods are non-living and are made by the aquarist or bought already prepared for consumption for fish (Axelrod et al. 1996). Fish feed should ideally provide the fish with fat and amino acids. Feed whether flaked or pellet must be assimilated in order to prevent build up of intestinal gas, renal failure and infections (such as swim bladder inflammation and dropsy) and to avoid aquarium pollution due to excessive ammonia release from gill, in urine and by feaces (Godard 1996).Some aquarium fish foods also contain additives such as steroids (Silva and Anderson 1995) or beta carotene to artificially enhance the color of the fish (Guillaume et al. 2001). Though the sector of ornamental fish and their feed is a developing sector in Bangladesh, there are very few literature found about the species and price of aquarium fish (Chowdhury et al. 2005, Kangkon 2013) but none about their feed composition or microbial quality. So this study was conducted to assess the biochemical composition and microbial quality of aquarium fish feed commonly found in Bangladesh. 


\section{MATERIAL AND METHODS}

Collection and preparation of samples: Three commercial aquarium fish feed samples of Super Nova ${ }^{\mathrm{TM}}$, Osaka $2000^{\mathrm{TM}}$ and Optimum ${ }^{\mathrm{TM}}$ were obtained from the aquarium fish feed market in Kataban, Dhaka in June 2014. They are all imported. Various information labeled in the three aquarium fish feed and the biochemical composition as labeled by the manufacturer have shown in Table 1. The biochemical composition and microbial quality of the samples were analyzed in the laboratory of Department of Fisheries, University of Dhaka by using Standard methods as follows:

Moisture: For the determination of moisture content, the initial weights were taken first and then samples were dried in an oven at about $105^{\circ} \mathrm{C}$ for about 10 to $18 \mathrm{hrs}$ until a constant weight was reached and cooled in desiccators and weights of the samples were taken again. Then the samples were minced in an electric grinder. The percentage of moisture content was determined according to AOAC (1995). The percentage of moisture was determined as Moisture content $(\%)=($ Weight loses $/$ original weight of sample $) \times 100$.

Ash: Ash content was estimated as inorganic residue left over after the organic matter has been burnt away at about $600-700{ }^{\circ} \mathrm{C}$. The sample was first burnt on a flame until it became charred and then in muffle furnace at about $600-700{ }^{\circ} \mathrm{C}$ till the residue become white. The crucibles were cooled in desiccators and weighed. Ash content was determined as $(\%)$ of Ash $=\{$ Final weight (g)-Crucible weight (g) $/$ /Sample weight $(\mathrm{g}) \times 100 \times$ Moisture factor $(\mathrm{AOAC}$, 1995).

Protein: The protein content was determined by micro Kjeldahl method (AOAC 1995). Alkali was added to the sample to convert ammonium $\left(\mathrm{NH}_{4}\right)$ to ammonia. The ammonia absorbed in the receiving flask containing receiver solution was titrated with $\mathrm{N} / 70 \mathrm{H}_{2} \mathrm{SO}_{4}$. Similarly a reagent blank was distilled and titrated. This determines percentage nitrogen that was multiplied by 6.25 to obtain the value of crude protein. The percentage of nitrogen in the sample was calculated as \% of Protein $=\{(\mathrm{S}-\mathrm{B}) \times 2.9 \times$ Moisture factor $\} /$ Weight of sample; where, $\mathrm{S}=$ Titration reading for sample, $\mathrm{B}=$ Titration reading for blank and Moisture factor $=(100$-Moisture content $) / 100$.

Lipid: Lipid was determined according to the modified method described by Folch et al. (1957). Briefly, at first 4-5 grams of dry sample was taken in a conical flask and about $20 \mathrm{ml}$ of chloroform: methanol (2:1) solution was added. The sample was allowed to stand for overnight and was filtered. The filtrate was taken in a separating funnel and $20 \mathrm{ml}$ of $0.58 \% \mathrm{NaCl}$ solution was added. The separating funnel was vigorously shaken for proper mixing and allowed to stand for 4-6 hours. The lower phase washed with sodium chloride solution repeatedly 


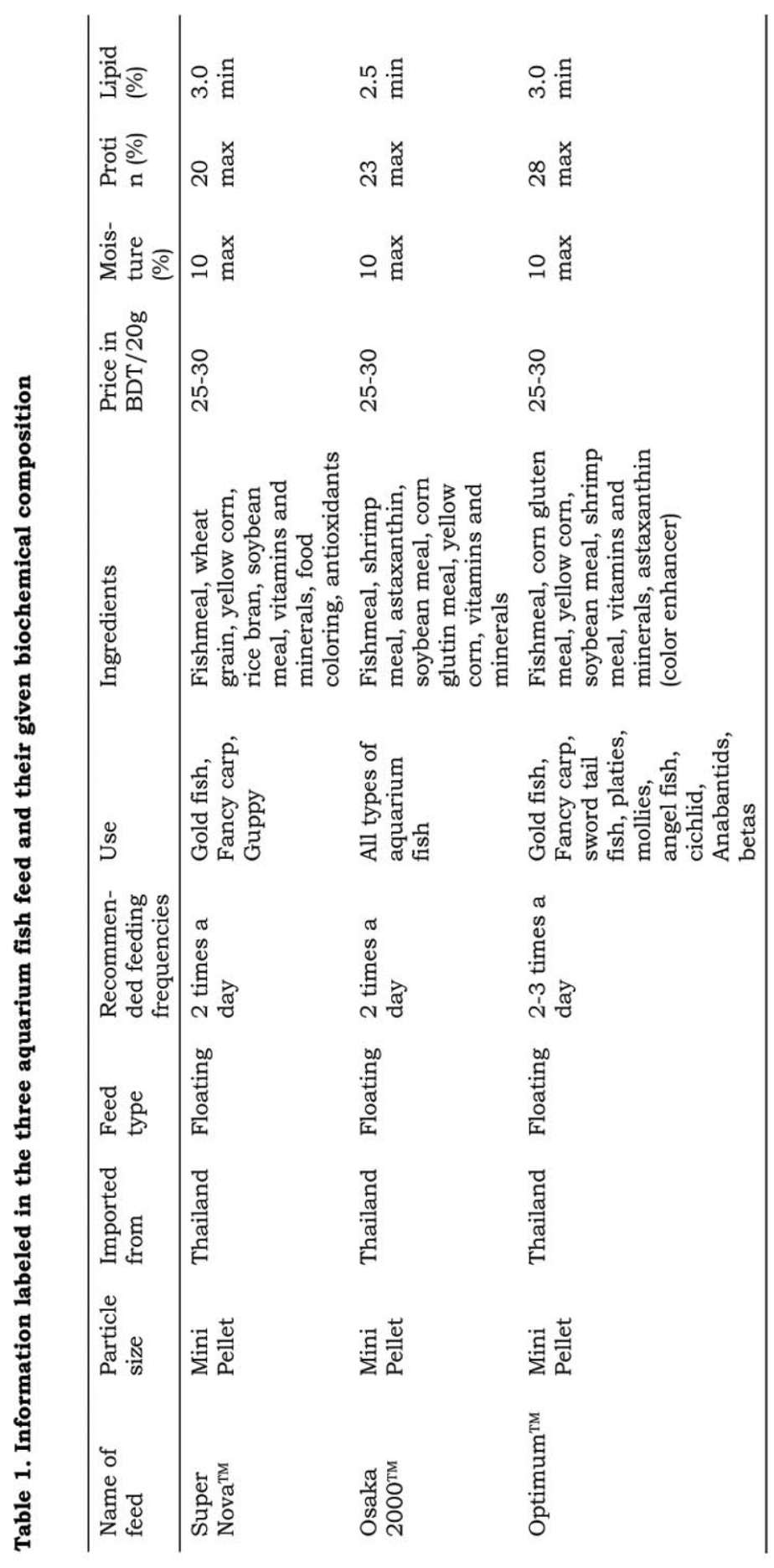


till the lower phase was clear. Finally the lower phase was collected in a conical flask. Total volume of extract was recorded. Then $5-10 \mathrm{~mL}$ of the extract was taken in $25 \mathrm{~mL}$ beaker and allowed to air dry and then dried in an oven at $60{ }^{\circ} \mathrm{C}$ for the determination of total lipid was determined gravimetrically. Lipid content was calculated as Lipid $(\%)=\{$ Final weight $(\mathrm{g})$-Flask weight $(\mathrm{g})\} /$ Sample weight $\times 100 \times$ Moisture factor.

Total Aerobic Bacteria: Nutrient agar was used to determine the total bacterial count. One gram sample was taken in $9 \mathrm{~mL}$ sterile normal saline to prepare a $10^{-1}$ dilution. Then, subsequent serial dilutions were prepared from $10^{-1}$ to $10^{-5}$. The spread plate technique was used to enumerate the total bacterial density. A sub-sample of $100 \mu \mathrm{L}$ from each dilution with three replicates was used to count bacteria as colony forming unit per gram (cfug-1). Bacterial density as cfug- $^{-1}$ for 3 replicates were initially averaged and used for final calculation (Mandal et al. 2009). All equipment and chemicals used were sterilized properly prior to use.

Detection of Escherichia coli: For the isolation and enumeration of E. coli, 100 $\mu \mathrm{L}$ of serially diluted sample were spread on to the McConkey agar plates and incubated at $44{ }^{\circ} \mathrm{C}$ for 18 to 24 hours. Pink colonies were counted as E. coli.

Detection of Vibrio cholerae: $25 \mathrm{~g}$ sample was taken in $225 \mathrm{~mL}$ sterile Alkaline Peptone Water aseptically and incubated at $37{ }^{\circ} \mathrm{C}$ for 24 hours. After incubation a loop full of medium was streaked on the Thiosulphate Citrate Bile Salt Sucrose Agar plate and incubated at $37{ }^{\circ} \mathrm{C}$ for 24 hours. The characteristics colonies, yellow, 2-3 $\mathrm{mm}$ diameter, slightly flatten with adequate center and translucent peripheries were suspected for $V$. cholerae. Then the suspected colonies were confirmed biochemically with some modifications (McFaddin 1980). Biochemical tests included TSI, K1A, Salt tolerance $(0 \%, 6 \%$ and $8 \%)$ oxidase reaction, strains motility, fermentation of carbohydrates (Glucose, Sucrose, Arabinose, Mannose, Mannitol and Inositol) Decarboxylase (Lysine, Arginine and Ornithine).

Detection of Staphylococcus aureus: For the isolation and enumeration of $S$. aureus, $100 \mu \mathrm{L}$ serially diluted samples was spread onto the manitol salt agar plates and incubated at $37{ }^{\circ} \mathrm{C}$ for 18 to 24 hours. Golden colonies were counted as $S$. aureus.

Statistical analysis: The means of different parameters were compared using ANOVA followed by Tukey's post hoc for multiple comparisons. Statistical software SPSS version 20 was used to analyze the data with the level of significance at $\mathrm{p}<0.05$. 


\section{RESULTS AND DISCUSSION}

Aquarium fishes are more sensitive to environment as well as feed on which they live. Ornamental fish growth, reproduction and other physiological activities depends on good quality of food that means balanced diets. According to Daniels and Robinsons (1986) and Van der Meer et al. (1997) excessive energy in diets could hamper the body growth and increase the lipid deposition as they have not necessary nutrient for body growth. In Dhaka City of Bangladesh only three types of aquarium fish feeds are common. Moreover there is no monitoring authority to check the quality of fish feed. So the aquarists depend on the information supplied by the companies (Ayubu and Iorkohol 2013).

Nutritional composition of various aquarium fish feed: Moisture content found in Super Nova ${ }^{\mathrm{TM}}(2.12 \pm 0.06 \%)$ was significantly higher than that of others $(\mathrm{p}<0.05, \mathrm{~F}=142.449)$. However, similar moisture content was detected in fish feed of Osaka $2000^{\mathrm{TM}}(0.69 \pm 0.08 \%)$ and Optimum ${ }^{\mathrm{TM}}(0.60 \pm 0.08 \%)$ (Fig. 1). Moisture content of fish feeds affects the quality of feed. High moist feeds sometimes invite the bacterial growth. The moisture level found in the study is under the range of values supplied by the manufacturer where all three feeds contained maximum $10 \%$ moisture.

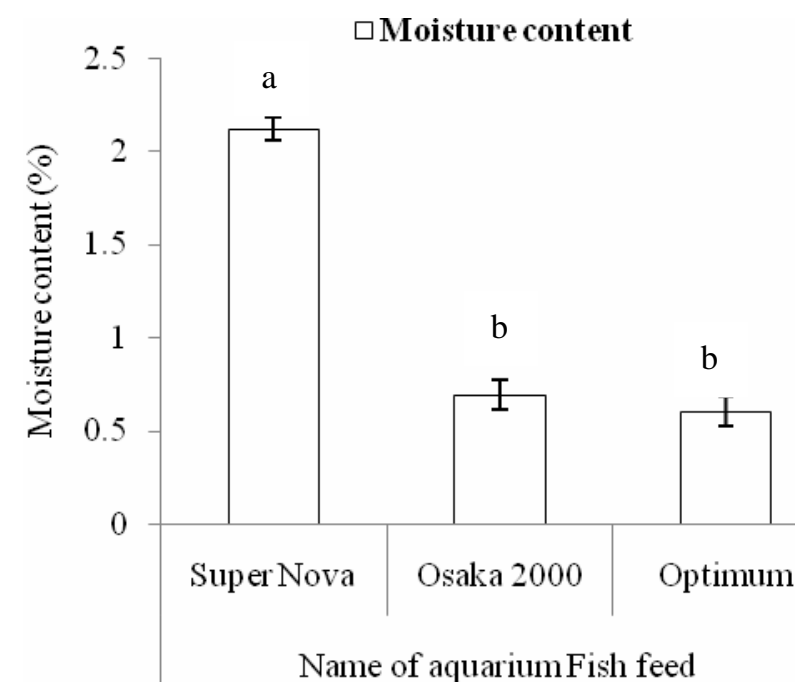

Fig. 1. Moisture content (\%) of different aquarium fish feed. Bars (mean \pm SEM) with different letters are significantly different (ANOVA, HSD; $\mathrm{p}<0.05$ ).

Ash content detected in Optimum ${ }^{\mathrm{TM}}$ and Osaka 2000 ${ }^{\mathrm{TM}}$ aquarium fish feed was significantly higher than that of Super Nova ${ }^{\mathrm{TM}}(10.67 \pm 0.19 \%)(\mathrm{p}<0.05, \mathrm{~F}=$ 20.778). However, ash content in Osaka 2000 ${ }^{\mathrm{TM}}(12.31 \pm 0.40)$ and Optimum TM (13.25 \pm 0.23 ) were similar ( $<<0.05$; Fig. 2). Range of ash content was $10.67 \pm$ 
$0.19 \%$ to $13.25 \pm 0.23 \%$ which might be sufficient for better growth of aquarium fish. No information was provided by the manufacturers about ash content in the feeds.

\section{Ash content}

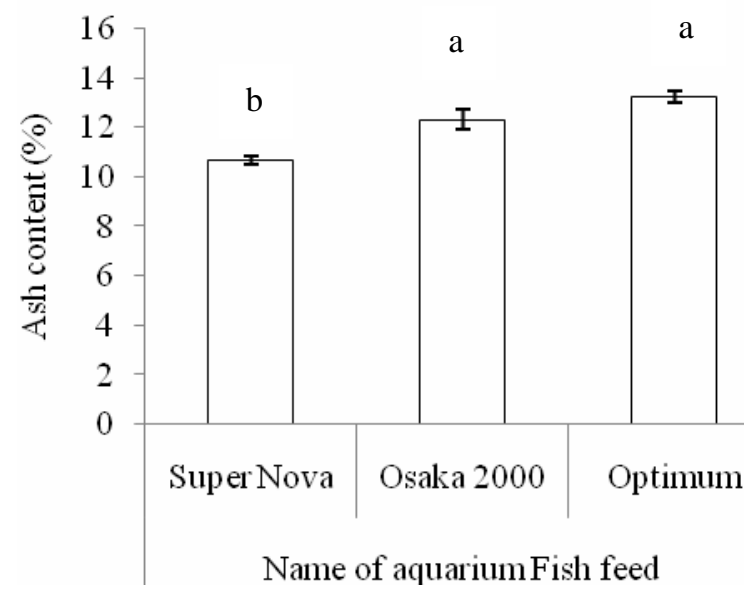

Fig. 2. Ash contents (\%) of different aquarium fish feed. Bars (mean \pm SEM) with different letters are significantly different (ANOVA, HSD; $\mathrm{p}<0.05$ ).

Protein content found in Optimum TM $(42.21 \pm 0.12 \%)$ was significantly higher than that of Osaka 2000TM and Super NovaTM $(\mathrm{p}<0.05, \mathrm{~F}=739.681)$. Moreover, protein content observed in Osaka $2000^{\mathrm{TM}}$ aquarium fish feed (36.72 \pm $0.14 \%)$ was significantly higher than that of Super $\operatorname{Nova}^{\mathrm{TM}}(\mathrm{p}<0.05$; Fig. 3). According to the manufacturers' information minimum protein level were 20, 23 and $28 \%$ in Super Nova ${ }^{\mathrm{TM}}$, Osaka $2000^{\mathrm{TM}}$ and Optimum ${ }^{\mathrm{TM}}$ respectively.

Protein plays an important role for body growth as well as in costing of feed. Protein requirements of ornamental fish depend on size, water temperature, feeding rate and available digestible energy in diets (Satoh 2000, Wilson 2000). Protein level found in the present study meets the requirement of ornamental fish according to the values supplied by the manufacturer. Protein requirement for tropical cat fish is $35-40 \%$ for fry, $25-35 \%$ for grow out and $28-32 \%$ for broodstock (Boonyaratpalin 1988). The fish body growth solely depends on protein utilization rate (Watanabe et al. 1990). In the present study protein level was $31.06 \pm 0.30 \%$ to $42.21 \pm 0.12 \%$ which is suitable for better growth of ornamental fish.

Similar lipid content was found in Optimum ${ }^{\mathrm{TM}}(1.06 \pm 0.03 \%)$ and Super Nova $^{\mathrm{TM}}(1.13 \pm 0.01 \%)$ aquarium fish feed which were significantly higher than that of Osaka $2000^{\mathrm{TM}}(\mathrm{p}<0.05, \mathrm{~F}=24.893$; Fig. 4). In general $10-20 \%$ of lipid in most freshwater fish diets gives optimal growth (Cowey and Sergeant 1979) but 
optimum level of protein is $5-6 \%$ (Wilson 2000) and for tilapia 5-6\% is Optimum (Luquet 2000). The range of lipid content in this study was found around 1\% which might not be suitable for better growth for ornamental fish, which also below the values supplied by the manufacturer for these aquarium fish feed. According to the manufacturers' information minimum lipid level were 3.0, 2.5 and $3.0 \%$ in Super Nova ${ }^{\mathrm{TM}}$, Osaka $2000^{\mathrm{TM}}$ and Optimum ${ }^{\mathrm{TM}}$ respectively.

\section{$\square$ Protein content}

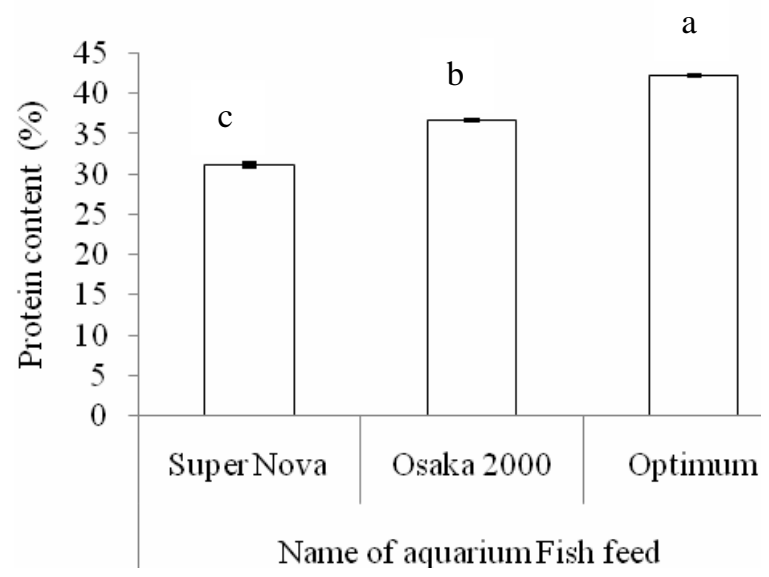

Fig. 3. Protein contents (\%) of different aquarium fish feed. Bars (mean \pm SEM) with different letters are significantly different (ANOVA, HSD; $\mathrm{p}<0.05$ ).

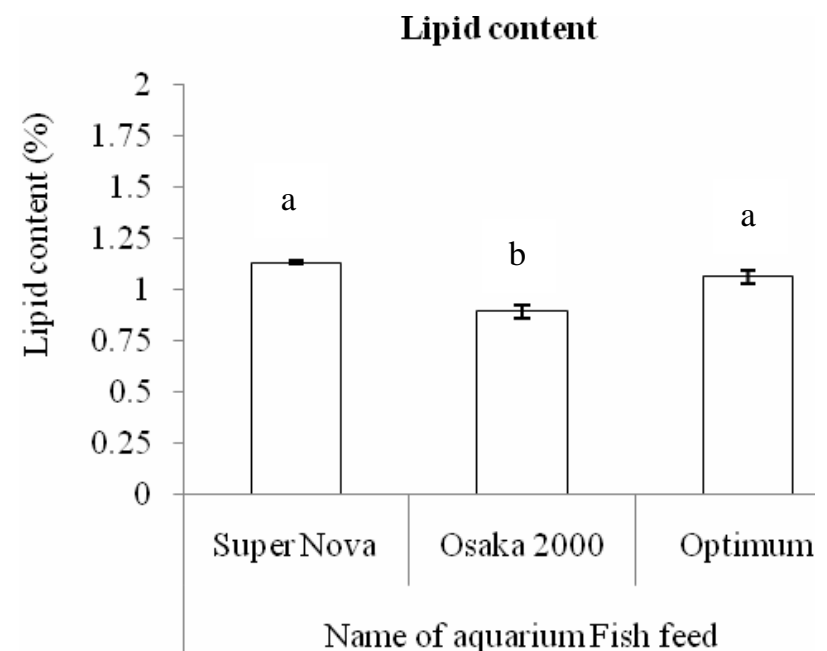

Fig. 4. Lipid contents (\%) of different aquarium fish feed. Bars (mean \pm SEM) with different letters are significantly different (ANOVA, HSD; $\mathrm{p}<0.05$ ). 
Microbial Analysis of various aquarium fish feed: Microbial contamination usually occurs if the feeds are kept in direct contact with water. The microbial contamination can be accelerating the spoilage of the feeds. The following microbial results were found in the three experimental aquarium fish feed named Super Nova ${ }^{\mathrm{TM}}$, Osaka $2000^{\mathrm{TM}}$ and Optimum ${ }^{\mathrm{TM}}$ :

Total bacterial count (TBC) in Osaka $2000^{\mathrm{TM}}$ fish feed was significantly higher $\left(3.16 \pm 0.05 \times 10^{5} \mathrm{cfug}^{-1}\right)$ than that of Super NovaTM $\left(6.93 \pm 0.09 \times 10^{4} \mathrm{cfug}^{-1}\right)$ and Optimum $^{\mathrm{TM}}\left(1.81 \pm 0.01 \times 10^{5} \mathrm{cfug}^{-1}\right)$ fish feed. However, in Optimum ${ }^{\mathrm{TM}}$ fish feed (TBC) was significantly higher than Super $\operatorname{Nova}^{\mathrm{TM}}(\mathrm{p}<0.05, \mathrm{~F}=2436.117$; Fig. 5).

\section{$\square$ Total bacterial count}

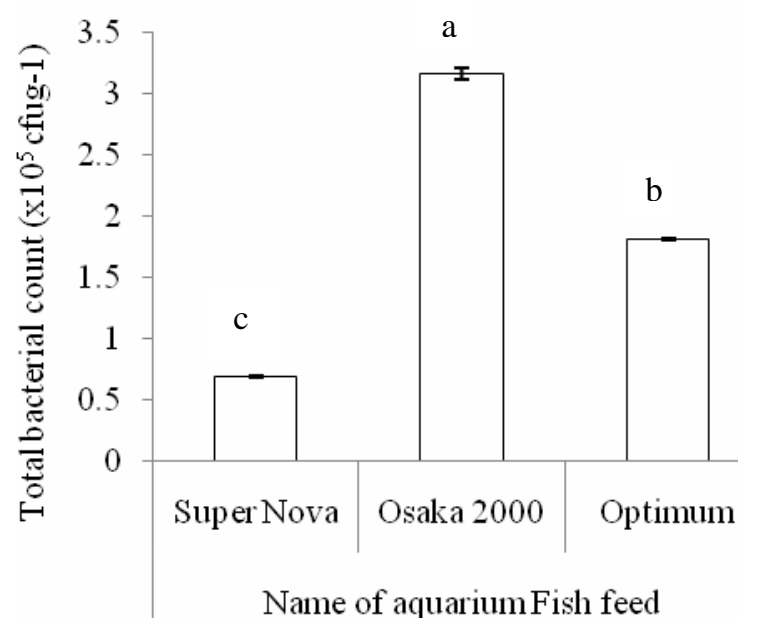

Fig. 5. Total bacterial count (cfug- ${ }^{-1}$ ) of different aquarium fish feed. Bars (mean \pm SEM) with different letters are significantly different (ANOVA, HSD; $\mathrm{p}<0.05$ ).

E. coli density found in Optimum ${ }^{\mathrm{TM}}$ fish feed $\left(6.20 \pm 0.05 \times 10^{3} \mathrm{cfug}^{-1}\right)$ was significantly higher than that of Super $\operatorname{Nova}^{\mathrm{TM}}\left(3.21 \pm 0.04 \times 10^{3} \mathrm{cfug}^{-1}\right)$ and Osaka 2000 ${ }^{\mathrm{TM}}\left(3.11 \pm 0.04 \times 10^{3} \mathrm{cfug}^{-1}\right)$ fish feed $(\mathrm{p}<0.05$; Table 4). However, $E$. coli density in Osaka $2000^{\mathrm{TM}}$ and Super Nova ${ }^{\mathrm{TM}}$ fish feed was similar to each other which were not significantly different from each other $(\mathrm{p}<0.05, \mathrm{~F}=1147.76$; Fig 6).

Density of Staphylococcus aureus observed in Super NovaTM aquarium fish feed $\left(4.33 \pm 0.09 \times 10^{3} \mathrm{cfug}^{-1}\right)$ was significantly higher than that of Osaka $2000^{\mathrm{TM}}$ $\left(2.88 \pm 0.04 \times 10^{3} \mathrm{cfug}^{-1}\right)$ and Optimum ${ }^{\mathrm{TM}}\left(2.17 \pm 0.03 \times 10^{3} \mathrm{cfug}^{-1}\right)(\mathrm{p}<0.05$, $\mathrm{F}=394.267$; Fig. 7). However, S. aureus in Osaka 2000TM was significantly higher than Optimum ${ }^{\mathrm{TM}}$ fish feed but significantly lower than Super Nova ${ }^{\mathrm{TM}}$ fish feed. $S$. aureus density in Optimum ${ }^{\mathrm{TM}}$ fish feed was significantly lower than that of others. 


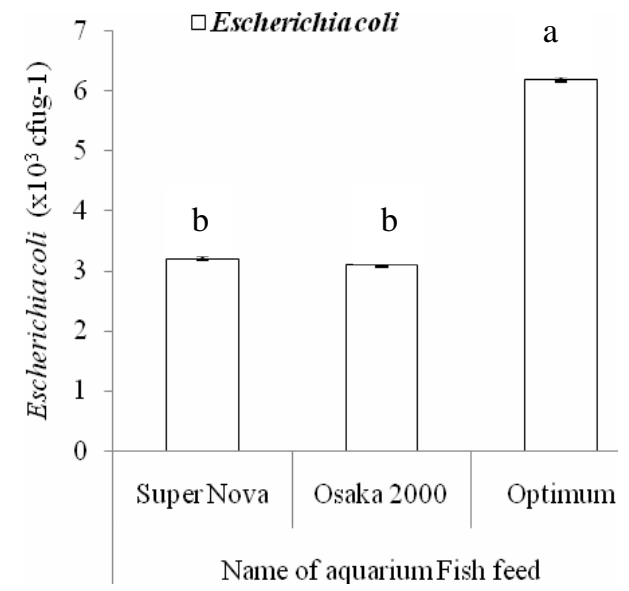

Fig. 6. Escherichia coli count $\left(\right.$ cfug- $\left.^{-1}\right)$ of different aquarium fish feed. Bars (mean \pm SEM) with different letters are significantly different (ANOVA, HSD; $\mathrm{p}<0.05$ ).

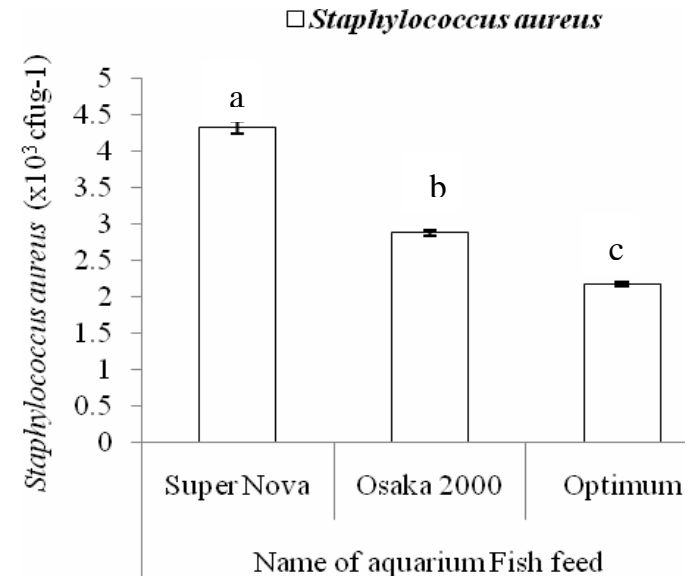

Fig. 7. Staphylococcus aureus count (cfug-1) of different aquarium fish feed. Bars (mean \pm SEM) with different letters are significantly different (ANOVA, HSD; $\mathrm{p}<0.05$ ).

No $V$. cholerae was found in any aquarium fish feed examined in the present study. Escherichia coli and Staphylococcus aureus were found in the present study which is supported by Nwabueze and Nwabueze (2011). Normally E. coli should not be present in any aquarium fish feed. E. coli has been found in these three fish feeds which may be due to contamination of feed stuff during feed manufacturing or improper storage condition, unhygienic condition of both the manufacturing system and unhygienic condition of staffs engaged in feed manufacturing. S. aureus may be present in fish but some strains of $S$. aureus is very injurious to fish and environment. When the water in aquarium become 
contaminated by this harmful $S$. aureus then that water become injurious to health of aquarium fish as well as to environment.

$E$. coli and other bacterial strains have been reported to contaminate fish feeds (Ciceron et al. 2008). According to Zmyslowska (2000), storage conditions especially temperature and humidity are important factors affecting microbial quality of fish feeds. Improper storage systems and condition such as temperature and humidity may extend the survival of the microorganism in fish feeds by accelerating their multiplication and production of toxic substances (Nwabueze and Nwabueze 2011).

E. coli contamination of fish feeds has been documented (Malicki et al. 2004). $E$. coli was the dominant micro-organism found in the aquarium fish feed. Unhygienic handling of feeds during sales and storage conditions may have influenced the type and bacterial counts in feeds observed (Nwabueze and Nwabueze 2011). Feeds that properly stored and free of contamination should be sold in market of Bangladesh.

It has been found that nutritional quality and microbial load of the examined fish feeds differed with the values supplied by the manufacturer. Aquarists get losses by using these types of feeds in rearing ornamental fishes. Thus, government should take proper initiative in quality control for the benefit of the aquarium fish industry in the country.

\section{LITERATURE CITED}

AOAC (Association of Official Analytical Chemists). 1995. Official Method of Analysis of AOAC International, $16^{\text {th }}$ ed., Washington DC.

AXELROD, H.R., EMMENS, C.W., BURGESS, W.E. and PRONEK, N. 1996. Exotic Tropical Fishes. T.F.H. Publications, Neptune city, NJ. $5^{\text {th }}$ rev and expanded ed. $1312 \mathrm{pp}$.

AYUBU, V.O. and IORKOHOL, E.K. 2013. Proximate composition of some commercial fish feeds sold in Nigeria. J. Fish. Aquat. Sci. 8(1): 248-252.

BOONYARATPALIN, M. 1988. Catfish feed. National Inland Fisheries Institute. Extension paper No.528 (in Thai). Department of Fisheries, Bangkok, Thailand.

CHAPMAN, F.A., FITZ-COY, S.A., THUNBERG, E.M. and ADAMS, C.M. 1997. United States of America trade in ornamental fish. J. World Aquacult. Soc. 28: 1-10.

CHEONG, L. 1996. Overview of the current international trade in ornamental fish, with special reference to Singapore, Revue Scientifique et Technique de l'Office International des Epizoonties, 15: $445-481$.

CHOWDHURY, M.M., RAKNUZZAMAN, M. and IQUBAL, K.F. 2005. A preliminary survey on the status and potential of aquarium fish and its trade in Bangladesh. Dhaka Univ. J. Biol. 14 (2): 137-145.

CICERON, M.F.A., DEL PRADO, J.M., ECHAUZ, J.J. and Cabrera, E.C. 2008. A comparative study on the antimicrobial resistance of Escherichia coli isolates of chickens and fish grown on integrated and traditional fish farms. The Philippine Agricultural Scientist. 91(3): 28-33. 
COWEY, C.B. and SERGEANT, J.R. 1979. Nutrition. In: Fish Physiology, Hoar, W.S., Randall, D.J. and Brett, J.R. (Eds). Academic press, London. pp. 1-69.

DANIELS, W.H. and ROBINSONS, E.H. 1986. Protein and energy requirements of juvenile red drum (Sciaenops ocellatus). Aquaculture 53: 243-252.

DAWES, J. 2001. International aquatic industry perspectives on ornamental fish conservation. In CHAO, L.N., PETRY, P., PRANG, G., SONNECHEN, L. and TLUSTY, M. (eds) Conservation and management of ornamental fish resources of the Rio Negro basin Amzonia Brazil-project Piaba. EDUA Manaus, Brazil. 100-121 pp.

FOLCH, J., LESS, M. and STANELY, G.H.S. 1957. A simple method for isolation and purification of total lipids from animal tissues. J. Biol. Chem. 26: 497.

GODDARD, S. 1996. Feed Management in Intensive Aquaculture. Chapman and \& Hall, 194 p.

GUILlAUME, J., KAUSHIK, S., BERGOT, P. and METAILLER, R. 2001. Nutrition and Feeding of Fish and Crustaceans. Praxis Publishing Ltd., UK. 183-196 pp.

KANGKON, R.H. 2013. Past and present status and prospectus of ornamental fishes in Bangladesh. (http://en.bdfish.org/2013/01/past-present-status-prospects-ornamental-fishes-bangladesh/ accessed on 08 November 2014).

LUQUET, P. 2000. Tilapia Oreochromis species. In: Handbook of Nutrient Requirement of Finfish, Wilson, R.P. (Ed). CRC Press, Boca Raton, USA. pp. 169-180.

MALICKI, A., ZAWADZKI, W., BRUZEWICZ, S., GRACZYK, S., CZERSKI, A. 2004. Effect of formic and propionic acid mixture on Escherichia coli in fish meal stored at $12^{\circ} \mathrm{C}$. Pakistan J. Nutr. 3(6): 353-356.

MANDAL, S.C., HASAN, M., RAHMAN, M.S., MANIK, M.H., MAHMUD, Z.H. and ISLAM, M.S. 2009. Coliform Bacteria in Nile Tilapia, Oreochromis nilotilcus of Shrimp-Gher, Pond and Fish Market. World J. Fish Marine Sci. 1(3): 160-166.

McFADDIN, J.F. 1980. Biochemical test for identification of medical bacteria. Waverly press Inc., Baltimore, Maryland, USA.

NWABUEZE, A.A. and NWABUEZE, E.O. 2011. Microbial flora of fish feeds sold in Asaba, Southern Nigeria. American J. Exp. Agricult. 1(2): 27-32.

RIEHL, R. and BAENSCH, H.A. 1996. Aquarium Atlas. 5th edn, Tetra Press, Germany.

SATOH, S. 2000. Common carp Cyprinus carpio. In: Handbook of nutrient requirement of fin fish. WILSON, R.P. (Ed.) CRC press. Boca Raton, USA. pp. 55-68.

SILVA, S.S.D and ANDERSON, T.A. 1995. Fish Nutrition in Aquaculture. Chapman \& Hall. 200, 209 p.

VAN DER MEER, M.B., Zamora, Z.E. and Verdegem, M.C.J. 1997. Effect of dietary lipid level on protein utilization and the size and proximate composition of body compartments of Colossoma macropomum (Cuvier). Aquacult. Res. 28: 405-417.

WHITTINGTON, R.J. and CHONG, R. 2007. Global trade in ornamental fish from an Australian perspective: the case for revised import risk analysis and management strategies. Prev. Vet. Med. 81: 92-116.

WILSON, R.P. 2000. Channel Catfish, Ictalurus punctatus. In: Handbook of Nutrient Requirement of Finfish, Wilson, R.P. (Ed). CRC Press, Boca Raton, USA. pp. 35-53.

WOOD, E.M. 2001. Collection of coral reef fish for aquaria: Global trade ,conservation issues and management strategies. Marine conservation Society, UK. 80 pp.

ZMYSLOWSKA, I. 2000. The effect of storage temperature on the Microbiological quality of fish feeds. Polish J. Env. Stud. 9(3): 223-226. 